\title{
EFEK KOPIGMENTASI DARI KATEKOL DAN TANIN TERHADAP STABILITAS ANTOSIANIN BEKATUL BERAS KETAN HITAM (Oryza sativa glutinosa) SELAMA PENYIMPANAN \\ [Copigmentation Effect Of Catechol And Tannin On Stability Of Glutinous Black \\ Rice Bran (Oryza sativa glutinosa) Anthocyanins During Storage]
}

\author{
Dian Wulandari ${ }^{*}$, Tirza Hanum dan Azhari Rangga \\ Jurusan Teknologi Hasil Pertanian UniversitasLampung \\ Jl. Prof. Dr. Soemantri Bojonegoro No.1 Bandar Lampung 35145 \\ *Email korespondensi: dianwulandari.unila@gmail.com
}

Diterima : 1 Agustus 2017

Disetujui : 1 Februari 2018

\begin{abstract}
Copigmentation has been suggested as an effective method to improve color and stability of anthocyanins as it is responsible for the increase in absorbance intencity (hyperchromism) and a positive shift in wavelength (bathochromism). Catechol and tannin can be used as a copigment to improve anthocyanin color stability for food applications. This study aims to examine the effect of molar ratio of catechol and tannin to the enhancement of color and stability of copigmented anthocyanins. Experiment was arranged in factorial Randomized Complete Block Design (RCBD) with three replications. First factor were molar ratio 0:1, 50:1, 100:1 and second factor were storage time $0,10,20,30$, 40 days at room temperature $\left(28^{\circ} \mathrm{C} \pm 2^{\circ} \mathrm{C}\right)$. Color and stability of anthocyanins were evaluated by determination of bathochromic, hyperchromic, concentration of anthocyanins and kinetic parameters. The data were analyzed using by ANOVA and further tested with Polynomial Orthogonal at 5 and $1 \%$ level. The results showed that anthocyanin content of glutinous black rice bran extract was $426 \mathrm{mg} / 100 \mathrm{~g}$. Copigmentation with catechol resulted in bluish color (hypsochromic), while tannin resulted in reddish color (bathochromic), both copigment resulted in hyperchromism. The best molar ratio of catechol to copigment was $50: 1$ showed by decreasing of anthocyanin concentration of $0.35 \mathrm{mM} /$ day or 39.29 $\mathrm{mg} / 100 \mathrm{~g} /$ day, color retention $12.78 \%$ /hour, and half-life time 8.66 hours. The best molar rasio of tannins copigment was 100: 1 showed by decreasing of anthocyanin concentrasion of $0.07 \mathrm{mM} /$ day or $7.86 \mathrm{mg} / 100 \mathrm{~g} / \mathrm{day}$, color retention was $2.39 \% /$ day, and half-life time of 19.80 hours.
\end{abstract}

Keywords: copigmentation, catechol, tannin, anthocyanins, glutinous black rice bran

\begin{abstract}
ABSTRAK
Metode kopigmentasi dapat digunakan untuk memperbaiki warna dan stabilitas antosianin selama penyimpanan. Katekol dan tanin dapat digunakan sebagai kopigmen untuk menstabilkan warna antosianin pada pangan. Penelitian ini bertujuan untuk mengetahui pengaruh jenis kopigmen terhadap warna antosianin terkopigmentasi, rasio molar katekol dan tanin terbaik selama penyimpanan. Metode penelitian disusun menggunakan Rancangan Acak Kelompok Lengkap (RAKL) faktorial dengan tiga ulangan. Faktor pertama adalah rasio molar yaitu $0: 1 ; 50: 1 ; 100: 1$; dan factor kedua adalah lama penyimpanan selama $0,10,20,30$, dan 40 hari. Data Warna dan stabilitas antosianin didapat dari pengamatan efek batokromik dan hiperkromik, perubahan konsentrasi antosianin selama penyimpanan, retensi warna, dan waktu paruh. Efek batokromik dan hiperkromik serta waktu paruh dianalisis secara deskriptif. Data dianalisis dengan
\end{abstract}


menggunakan ANOVA dan uji lanjut Polinomial Ortogonal pada $\alpha_{0,05}$ dan $\alpha_{0,01}$. Hasil penelitian menunjukkan bahwa kandungan antosianin dari ekstrak bekatul beras ketan hitam adalah $426 \mathrm{mg} / 100 \mathrm{~g}$. Kopigmen dengan menggunakan katekol memberikan pengaruh warna kebiruan (hipsokromik), sedangkan kopigmen tanin memberikan warna kemerahan (bathokromik) setelah proses kopigmentasi antosianin ekstrak bekatul beras ketan hitam (Oryza sativaglutinosa). Rasio molar terbaik pada kopigmen katekol adalah 50:1 dengan penurunan konsentrasi antosianin sebesar $0,35 \mathrm{mM} / \mathrm{hari}$ atau $39,29 \mathrm{mg} / 100 \mathrm{~g} / \mathrm{hari}$, laju penurunan retensi warna sebesar $12,78 \%$ /hari, dan waktu paruh 8,66 jam. Rasio molar terbaik pada kopigmen tanin adalah 100:1 dengan penurunan konsentrasi antosianin sebesar $0,07 \mathrm{mM} /$ hari atau $7,86 \mathrm{mg} / 100 \mathrm{~g} /$ hari, laju penurunan retensi warna sebesar 2,39\%/hari, dan waktu paruh 19,80.

Kata Kunci: Kopigmentasi, katekol, tanin, antosianin, bekatul beras ketan hitam

\section{PENDAHULUAN}

Antosianin merupakan jenis pigmen merah ungu dari golongan flavonoid yang tersebar luas pada berbagai jenis tanaman (Castaneda et al., 2009), seperti pada bayam merah (Pebrianti et al., 2015), bunga sepatu (Setyadi, 2014), dan bunga telang (Mastuti, 2013). Menurut Mateus dan Freitas (2008) dan Kopjar dan Pilizota (2009), antosianin belum digunakan secara luas sebagai pewarna alami pangan karena stabilitasnya yang rendah dan dipengaruhi oleh kondisi lingkungan. Salah satu sumber pewarna alami yang berpotensi adalah bekatul beras ketan hitam yang merupakan produk samping dari industri beras ketan hitam. Bekatul beras ketan hitam, yang merupakan hasil samping proses penggilingan gabah ketan hitam berpotensi untuk diekstrak karena pada satu bulir nya mengandung $8 \%$ bekatul (bran) dan memiliki kandungan antosianin yang tinggi yaitu $1,89 \%$ berat basah bekatul (Mahkamah, 2004). Permasalahan yang sering dihadapi adalah ketidakstabilan antosianin selama pengolahan dan penyimpanan yang terutama dipengaruhi oleh $\mathrm{pH}$, suhu, cahaya, oksigen, struktur dan konsentrasi antosianin, dan kehadiran komponen lain seperti flavonoid lain, protein, dan mineral (Mazza dan Brouillard, 1990).
Salah satu cara yang dapat dilakukan untuk memperbaiki stabilitas antosianin adalah dengan kopigmentasi (Rein, 2005; dan Kalisz et.al, 2013). Kopigmentasi merupakan pembentukan ikatan antarmolekul pigmen dengan molekul kopigmen (flavonoid, alkaloid, flavonol, fenolik dan asam organik) melalui pembentukan ikatan yang memperkuat dan menstabikan warna (Talcot, et al, 2003; Darias-Martin et al., 2007; CastañedaOvando et al., 2009; Berké and Freitas, 2005). Bahkan dilaporkan juga bahwa penambahan ekstrak kasar kopigmen lebih baik dari ekstrak murni (Wilska-Jeszka dan Korzuchowska, 1996).

Kopigmen antosianin adalah suatu senyawa yang tidak berwarna atau berwarna lemah, pada umumnya agak kekuningan, atau senyawa berwarna yang terdapat secara alami pada sel tanaman di sekitar antosianin (Jackman dan Smith, 1996). Jenis kopigmen yang telah diteliti antara lain berasal dari golongan flavonoid (katekin dan epikatekin), alkaloid (kafein), flavonol polimer (tanin), fenolik (katekol dan metil katekol), asam amino, asam organik, nukleotida, polisakarida, logam bahkan antosianin sendiri (Kopjar and Pilizota, 2009). Penambahan kopigmen yang sama pada jenis antosianin yang berbeda dapat menunjukkan pengaruh 
yang berbeda, demikian juga sebaliknya. Hal ini dibuktikan oleh Scheffeldt dan Hrazdina (1978) yang melaporkan bahwa penambahan kopigmen rutin pada malvidin-3-glucoside, malvidin-3-pcoumarylglucoside, malvidin-3.5diglucoside dan malvidin-3-pcoumarylglucoside-5-glukosida pada kondisi yang sama menunjukkan peningkatan intensitas warna yang berbeda. Oleh karena itu, perlu dilakukan penelitian lebih lanjut untuk mengetahui efektivitas kopigmen katekol dan tanin terhadap stabilitas antosianin bekatul ketan hitam. Katekol dan tanin dipilih karena banyak terdapat pada bahan non pangan (kulit, kayu, daun) sehingga apabila terbukti efektif, penggunaan bahan nonpangan sebagai kopigmen tidak akan mengurangi sumber pangan.

Rasio molar yang terlalu rendah pada proses kopigmentasi menyebabkan penggunaan kopigmen tidak efisien, begitu juga apabila penggunaan rasio terlalu tinggi (Boulton, 2001). Oleh karena itu, pada penelitian ini akan dipelajari lebih lanjut pengaruh jenis dan rasio molar kopigmen yang tepat terhadap antosianin yang dapat menguatkan dan menstabilkan warna antosianin.

\section{BAHAN DAN METODE}

\section{Tempat dan Waktu Penelitian}

Bahan yang digunakan dalam penelitian ini adalah bekatul beras ketan hitam (Oryza sativaglutinosa) dengan kadar air $12.58 \%$ yang diperoleh dari Tanjung Bintang Lampung Selatan, kopigmen tanin dan katekol (SIGMA Aldrich), dan bahan kimia pendukung lainnya. Alat-alat yang digunakan dalam penelitian ini adalah rotary vacuum evaporator, spektrofotometer merk varian type cary 50 probe, centrifuge merk hitachi type CF16RX II, shaker, oven, dan $\mathrm{pH}$ meter.

\section{Metode Penelitian}

Penelitian dilakukan dalam 2 percobaan terpisah (tanin atau katekol) yang masing-masing menggunakan Rancangan Acak Kelompok Lengkap (RAKL) disusun secara faktorial $(3 \times 5)$ dalam 3 ulangan dengan faktor pertama adalah rasio molar kopigmen terhadap antosianin; 0:1, 50:1, 100:1 dan faktor kedua adalah lama penyimpanan; 0, 10, 20, 30, dan 40 hari. Data spektrofotometrik dan waktu paruh larutan antosianin terkopigmentasi pada suhu $65^{\circ} \mathrm{C}$ dianalisis secara deskriptif. Data perubahan konsentrasi antosianin selama penyimpanan dan perubahan retensi warna diuji kemenambahan datanya dengan menggunakan uji Tuckey dan kesamaan ragam data diuji dengan menggunakan uji Bartlet. Data dianalisis menggunakan analisis ragam untuk mendapatkan penduga ragam galat dan mengetahui ada tidaknya pengaruh perlakuan, kemudian pengujian dilanjutkan dengan perbandingan ortogonal dan polinomial ortogonal pada taraf nyata $5 \%$ dan $1 \%$ (Steel dan Torrie, 1991).

\section{Pelaksanaan Penelitian}

\section{Ekstraksi pigmen antosianin bekatul beras ketan hitam}

Ekstraksi antosianin dari bekatul beras ketan hitam dilakukan dengan metode ekstraksi Francis dan Bassa (1987), dan Gao dan Mazza (1996). Bekatul beras ketan hitam sebanyak $100 \mathrm{~g}$ di masukan ke dalam $250 \mathrm{~mL}$ metanol (yang telah diasamkan dengan $1 \% \mathrm{HCl}$ ) kemudian diekstrak sambil diaduk menggunakan shaker kecepatan $125 \mathrm{rpm}$, selama 2 jam kemudian didiamkan tanpa 
pengadukan sampai 24 jam pada suhu ruang $\left(28^{\circ} \mathrm{C} \pm 2^{\circ} \mathrm{C}\right)$. Selanjutnya sampel disaring menggunakan kain saring dan kertas saring Wathman no 42 untuk memisahkan padatan dan larutan ekstrak. Filtrat hasil penyaringan dipekatkan dengan rotary vacuum evaporator pada suhu $45^{\circ} \mathrm{C}$ selama 2 jam sehingga menghasilkan kondensat (metanol) dan ekstrak antosianin pekat. Cuplikan ekstrak diambil untuk penentuan konsentrasi awal antosianin.

\section{Penentuan konsentrasi antosianin ekstrak bekatul beras ketan hitam}

Cuplikan sampel pekat hasil ekstraksi diencerkan menggunakan buffer sitrat $\mathrm{pH} \quad 3,5$ hingga $120 \mathrm{~mL}$ dan disentrifus pada kecepatan $10.000 \mathrm{rpm}$ pada suhu $5^{\circ} \mathrm{C}$ selama 10 menit. Sampel hasil sentrifus diencerkan hingga berada pada absorbansi dengan selang $0,4-0,8$ pada panjang gelombang $520 \mathrm{~nm}$. Konsentrasi antosianin dinyatakan sebagai sianidin -3-glukosida dan dihitung menggunakan persamaan berikut :

Absorban sampel (A)

$\mathrm{A}=\left(\mathrm{A}_{\lambda \max }-\mathrm{A}_{700}\right)_{\mathrm{pH} \mathrm{1,0}}-\left(\mathrm{A}_{\lambda \max }-\mathrm{A}_{700}\right)_{\mathrm{pH}}$ 4,5

Total antosianin $(\mathrm{mM})$

$\mathrm{mM}=(\mathrm{A} \times \mathrm{DF} \times 1000) /(\varepsilon \times 1)$

Total antosianin $(\mathrm{mg} / \mathrm{L})$

$\mathrm{mg} / \mathrm{L}=(\mathrm{A} \times \mathrm{MW} \times \mathrm{DF} \times 1000) /(\epsilon \times 1)$

Keterangan:

$\mathrm{A}_{\lambda \max }=$ Absorban pada panjang gelombang maksimal

MW Sianidin 3-glukosida $=449,2 \mathrm{~g} / \mathrm{mol}$

$\mathrm{DF}=$ Faktor pengenceran,

Absortivitas Molar $=\varepsilon=26.900 \mathrm{~L} / \mathrm{mol} / \mathrm{cm}$

\section{Kopigmentasi antosianin bekatul beras ketan hitam}

Reaksi kopigmentasi dilakukan dengan mencampur $35 \mathrm{~mL} \quad 0,2 \mathrm{mM}$ ekstrak antosianin bekatul beras ketan hitam dengan kopigmen (tanin atau katekol) sesuai dengan perlakuan rasio molar masing-masing. Perhitungan konsentrasi kopigmen yang akan ditambahkan menggunakan persamaan berikut:

Konsentrasi kopigmen $=\mathrm{C} x \mathrm{BM} \mathrm{x}$ $\mathrm{V} / 1000 \times \mathrm{R}$

Keterangan:

$\mathrm{C}=$ Konsentrasi antosianin awal (mM)

$\mathrm{BM}=$ Berat molekul kopigmen $(B M$ katekol $=110,11 \mathrm{mg} / \mathrm{mM}$ dan BM tanin $1701 \mathrm{mg} / \mathrm{mM}$ )

$\mathrm{V}=$ Volume ekstrak $(35 \mathrm{~mL})$

$\mathrm{R}=\operatorname{Rasio}(0: 50: 100)$

Berdasarkan perhitungan rumus di atas, jumlah kopigmen yang harus ditambahkan adalah katekol sebanyak 38,54 mg untuk rasio mol 50:1 dan 77,07 mg untuk rasio molar 100:1; tanin sebanyak 595,35 mg untuk rasio molar 50:1 dan 1.190,70 mg untuk rasio molar 100:1. Masing-masing kopigmen tersebut ditambahkan ke dalam botol gelap bertutup yang telah diisi dengan $35 \mathrm{~mL}$ ekstrak antosianin dan dihomogenkan dengan shaker pada kecepatan 100 rpm selama 10 menit. Ekstrak antosianin yang telah dicampur dengan kopigmen selanjutnya disimpan di tempat yang terpapar cahaya pada suhu kamar $\left(28^{\circ} \mathrm{C} \pm\right.$ $2^{\circ} \mathrm{C}$ ), dan dianalisis pada hari ke $0,10.20$, 30, dan 40.

\section{Pengamatan}

\section{Pengaruh kopigmentasi terhadap batokromik dan hiperkromik}

Sampel antosianin yang tidak dikopigmentasi (rasio molar 0) dan antosianin yang dikopigmentasi (rasio molar 50 dan 100), masing-masing dimasukkan ke dalam $6 \mathrm{~mL}$ larutan buffer 
$\mathrm{pH}$ 3,5 pada pengenceran yang menunjukkan absorban pada $\lambda 520 \mathrm{~nm}$ berada antara 0,4-0,8. Kemudian absorbansi sampel dibaca dengan spektrofotometer (Scanning) pada berbagai panjang gelombang $450 \mathrm{~nm}-600$ $\mathrm{nm}$ sampai diperoleh Absorban tertinggi $\left(\mathrm{A}_{\lambda \max }\right)$ (Rein, 2005). Scanning pada spektrofotometer dilakukan pada hari ke10 untuk mengamati perubahan absorbansi maks (hiperkromik) dan pergeseran $\lambda$ maks (batokromik).

\section{Perubahan konsentrasi antosianin selama penyimpanan}

Perubahan konsentrasi antosianin selama penyimpanan dihitung menggunakan metode perbedaan $\mathrm{pH}$ pada Spektrofotometer (Giusti dan Worlstad, 2001)

\section{Retensi warna}

Absorban warna ekstrak antosianin bekatul beras ketan hitam yang tidak dikopigmentasi maupun dikopigmentasi selama penyimpanan dibaca pada larutan buffer 3,5 pada $\lambda 520$ nm (Rein dan Heinonen, 2004). Warna ekstrak antosianin merupakan gabungan dari warna yang bersumber dari antosianin dan warna dari senyawa flavonoid lain $\left(\lambda_{700}\right)$. Pada pH 3,5 antosianin dan flavonoid lainnya berada dalam struktur yang stabil sehingga pengamatan retensi warna dibaca pada $\mathrm{pH} 3,5$. Retensi warna selama penyimpanan dihitung dengan rumus :

Retensi Warna $(\%)=\left(\mathrm{A}_{t} / \mathrm{A}_{0}\right) \times 100 \%$

Keterangan :

$\mathrm{A}_{0}$ : absorban pada hari ke- 0

$\mathrm{A}_{\mathrm{t}}$ : absorban pada hari ke-t

\section{Waktu paruh}

Perhitungan waktu paruh dari degradasi antosianin berdasarkan pada perubahan konsentrasi antosanin pada suhu pemanasan $65^{\circ} \mathrm{C}$ dalam jangka waktu 8 jam yang dibaca secara spektrofotometri. Larutan antosianin yang dipanaskan menggunakan waterbath dibaca absorbansinya dengan interval waktu 2 jam. Penentuan konsentrasi antosianin dilakukan dengan melarutkan $0,2 \mathrm{mM} \mathrm{ml}$ antosianin bekatul beras ketan hitam sebanyak $0,5 \mathrm{~mL}$ ke dalam $6 \mathrm{~mL}$ larutan buffer $\mathrm{pH} 1$ dan 4,5 (Shi and Francis, 1992). Waktu paruh $\left(\mathrm{t}_{1 / 2}\right)$ dari antosianin, dihitung dengan menggunakan persamaan laju reaksi ordo satu sebagai berikut (Kopjar dan Pilizota 2009):

$$
\mathrm{t}_{1 / 2}=-\frac{\ln 0,5}{\mathrm{k}}
$$

\section{HASIL DAN PEMBAHASAN}

\section{Kadar Antosianin Bekatul Beras Ketan Hitam}

Ekstraksi $100 \mathrm{~g}$ bekatul beras ketan hitam $(\mathrm{Ka}=12,58 \% \quad(\mathrm{~b} / \mathrm{b}))$ menghasilkan ekstrak kasar dengan kadar antosianin sebesar $3,79 \mathrm{mM}$ atau 426 $\mathrm{mg} / 100$ g. Jumlah tersebut lebih kecil dibandingkan dengan hasil penelitian yang dilakukan oleh Shao et.al. (2014) yang menghasilkan ekstrak murni dengan kadar antosianin sebesar $628,1 \mathrm{mg} / 100 \mathrm{~g}$. Perbedaan kadar antosianin mungkin dikarenakan perbedaan jenis bekatul beras ketan hitam dan tingkat kemurnian ekstrak.

\section{Pengaruh Kopigmentasi dengan Katekol terhadap Stabilitas Antosianin Ekstrak Bekatul Beras Ketan Hitam}

\section{Pengaruh kopigmentasi terhadap batokromik dan hiperkromik}

Hasil scaning berupa absorbansi antosianin ekstrak bekatul beras ketan hitam yang dikopigmentasi katekol dan kontrol disajikan pada Gambar 1. Kopigmentasi dengan katekol menggeser 
panjang gelombang maksimum $\left(\lambda_{\text {maks }}\right)$ ke panjang gelombang yang lebih kecil sehingga menunjukkan warna kebiruan (hipsokromik). Pada kurva perbandingan rasio molar 50:1 terjadi hipsokromik $0,53 \%$ yang ditunjukkan oleh warna sampel yang kebiruan dan penurunan absorbansi (hipokromik) 2,02\%. Sedangkan pada perbandingan rasio molar 100:1 juga terjadi hipsokromik 0,95\% namun teramati hiperkromik sebesar 20,03\%. Hal ini menunjukkan bahwa pada rasio kopigmen yang lebih besar
(100:1) kopigmentasi katekol mampu memperkuat warna antosianin. Hal ini didukung oleh laporan Markovic et. al.(2000); Kopjar dan Pilizota (2009) bahwa asam fenolat seperti katekol menunjukkan potensi dalam memperkuat dan menstabilkan warna antosianin. Rein (2005) melaporkan bahwa sianidin-3glukosida yang terkopigmentasi asam rosmarinat dapat meningkatkan absorbansi (hiperkromik) hingga114,40 \% dan batokromik 2,92\% (Gambar 2).

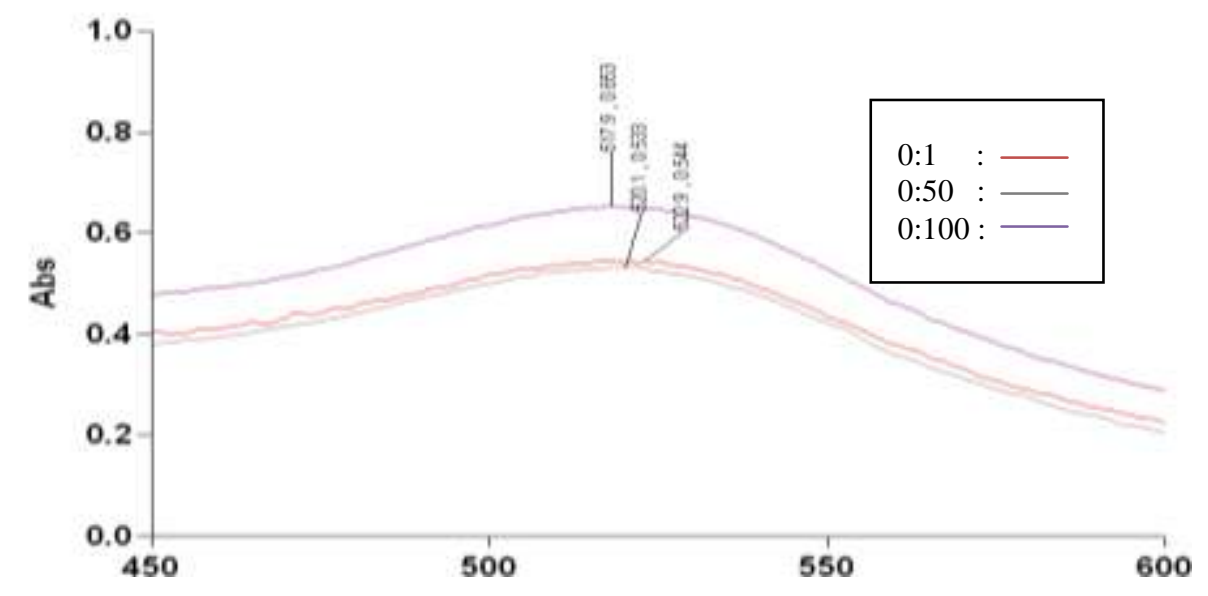

Gambar 1. Pengaruh kopigmentasi katekol terhadap batokromik dan hiperkromik antosianin ekstrak bekatul beras ketan hitam

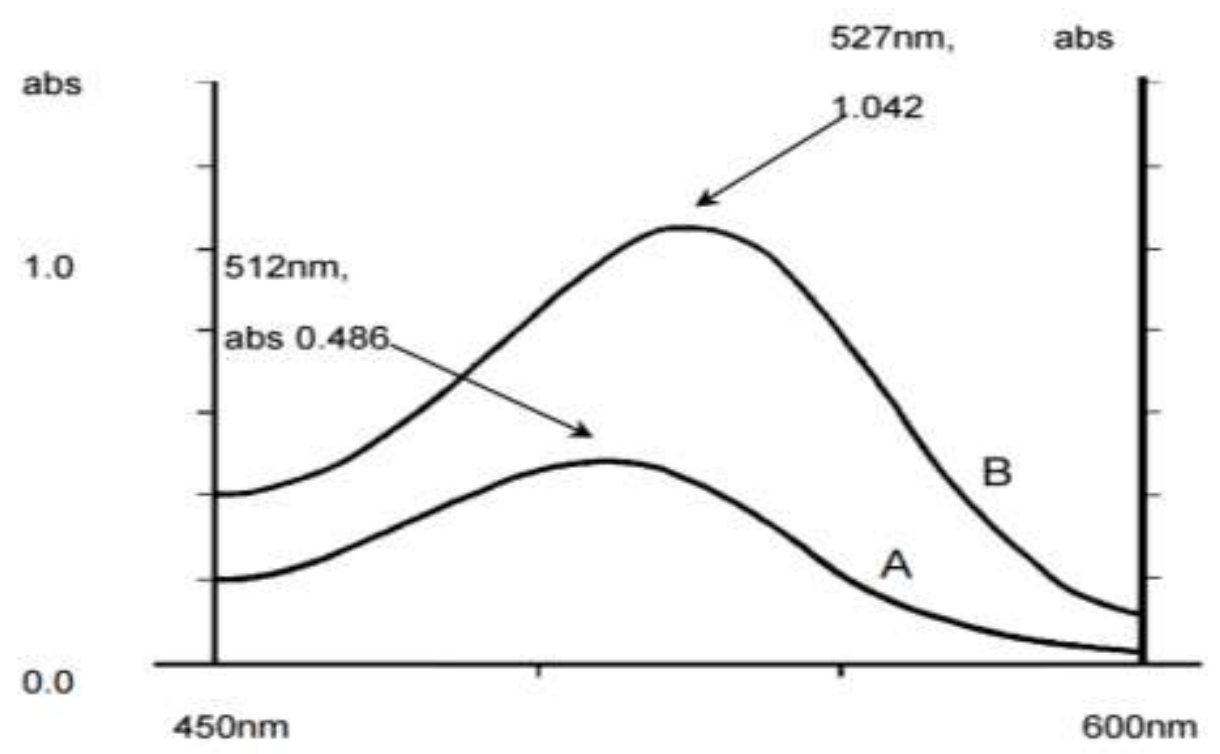

Gambar 2. Pengaruh kopigmentasi asam rosmarinat terhadap batokromik dan hiperkromik sianidin-3-glukosida (Rein, 2005) 


\section{Perubahan konsentrasi antosianin terkopigmentasi katekol selama penyimpanan}

Hasil analisis ragam menunjukkan bahwa perbandingan rasio molar katekol, lama penyimpanan, dan interaksi keduanya berpengaruh sangat nyata terhadap konsentrasi antosianin pada taraf $1 \%$ dan 5\%. Hasil uji kontras menunjukkan bahwa rasio molar 0:1 dan 50:1 berpengaruh sangat nyata secara linier sedangkan rasio molar 100:1 tidak berpengaruh nyata secara linier (Gambar
3). Antosianin ekstrak bekatul beras ketan hitam terkopigmentasi katekol padaperbandingan rasio molar 50:1 lebih stabil dari pada rasio molar 0:1 dan 100:1. Hal ini ditujukkan oleh laju penurunan konsentrasi antosianin rasio molar 50:1 yang terkecil yaitu $0,36 \mathrm{mM} / \mathrm{hari}$ atau $39,29 \mathrm{mg} / 100 \mathrm{~g} /$ hari. Jumlah penurunan antosianin pada rasio molar 50:1 lebih kecil dibandingkan dengan rasio molar 0:1 yang mengalami penurunan konsentrasi antosianin sebanyak $0,39 \mathrm{mM} / \mathrm{hari}$.

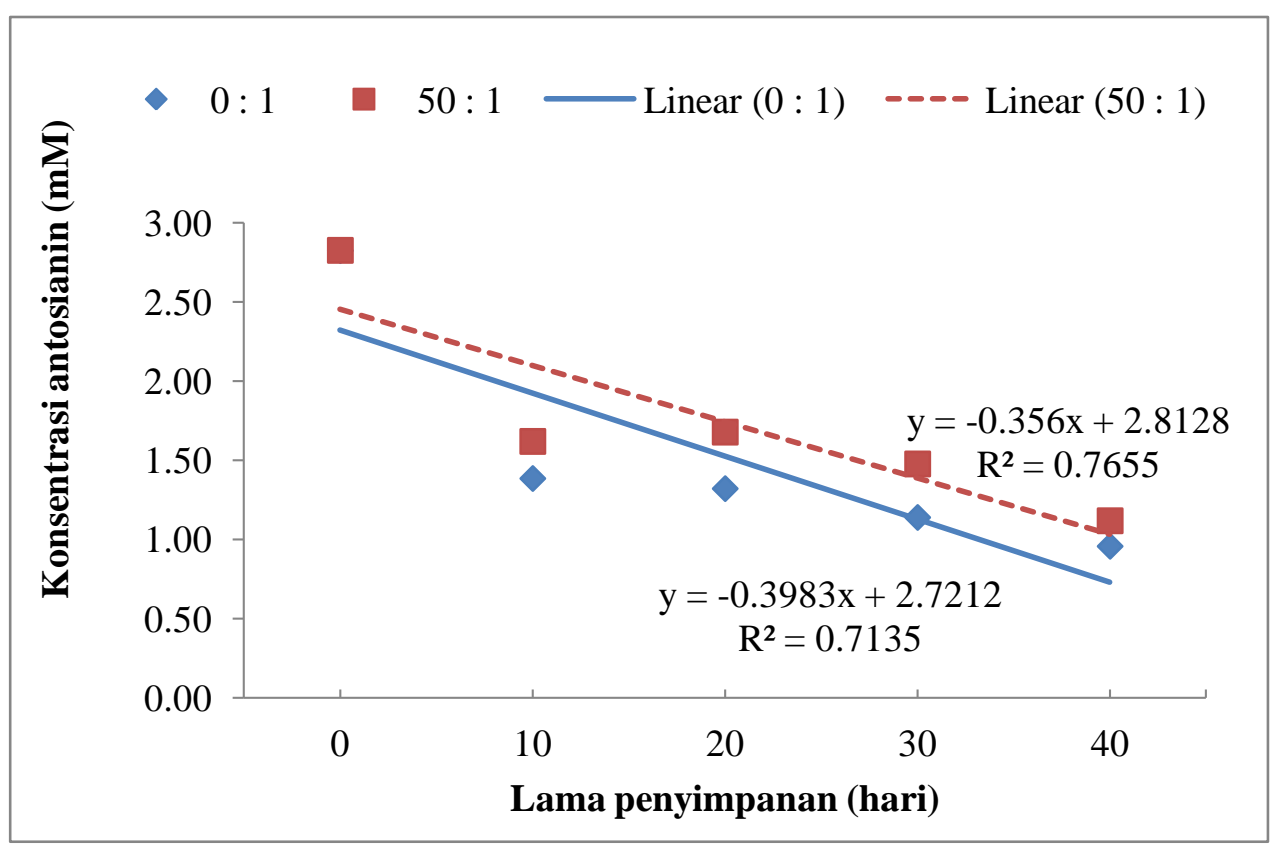

Gambar 3. Pengaruh kopigmentasi katekol terhadap konsentrasi antosianin ekstrak bekatul beras ketan hitam selama penyimpanan 


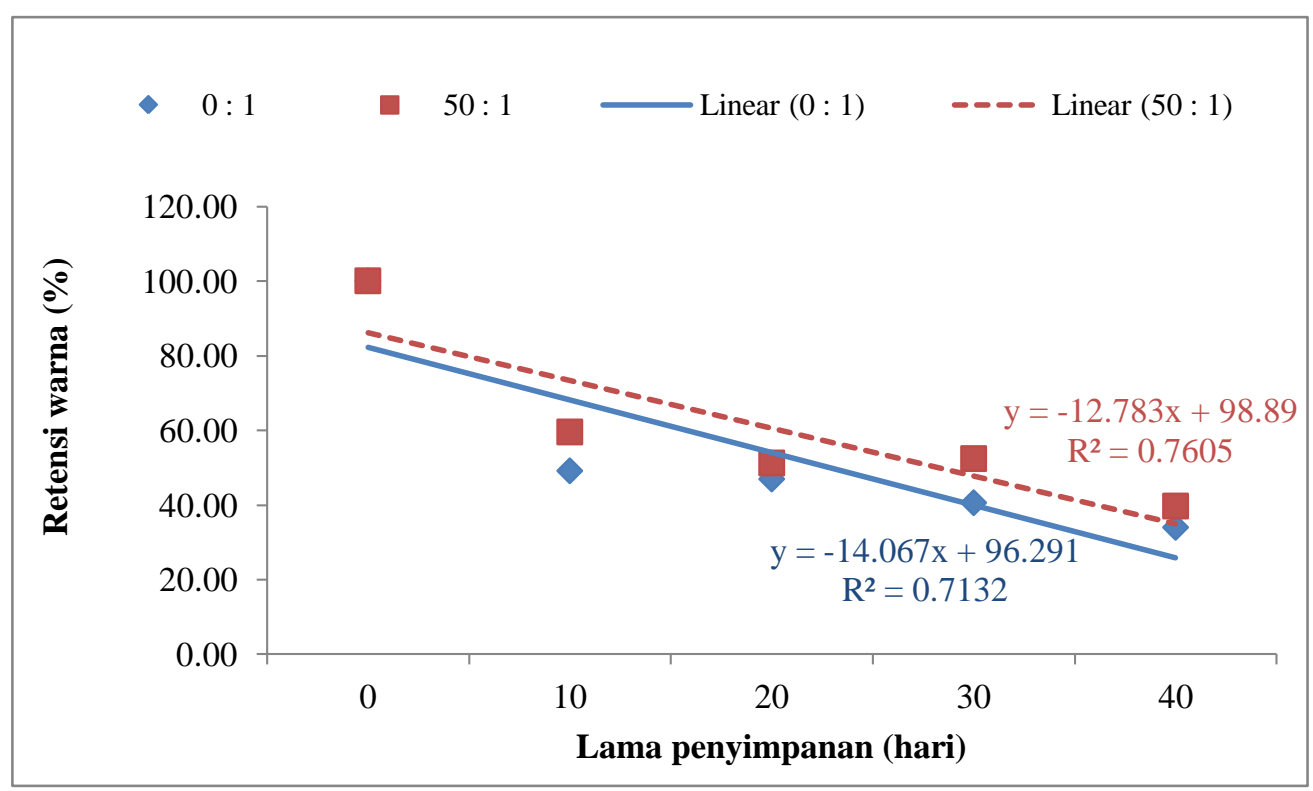

Gambar 4. Pengaruh kopigmentasi katekol terhadap retensi warna antosianin ekstrak bekatul beras ketan hitam selama waktu penyimpanan

\section{Perubahan retensi warna}

Hasil perhitungan analisis ragam menunjukkan bahwa perbandingan rasio molar katekol lama penyimpanan, dan interaksi keduanya berpengaruh sangat nyata terhadap retensi warna antosianin pada taraf $1 \%$ dan $5 \%$. Hasil uji kontras menunjukkan bahwa kopigmen katekol pada rasio molar 0:1 dan 50:1 berpengaruh sangat nyata secara linier sedangkan rasio molar 100:1 tidak berpengaruh nyata secara linier (Gambar 4).

Kopigmen katekol pada perbandingan rasio molar 50:1 dapat mempertahankan stabilitas antosianin ekstrak bekatul beras ketan hitam terbaik yang ditunjukkan oleh laju penurunan retensi warna antosianin terkecil yaitu sebesar $12,78 \%$ /hari. Pada penambahan kopigmen rasio molar 0:1, laju penurunan retensi warna antosianin ekstrak bekatul beras ketan hitam lebih tinggi yaitu $14,07 \%$ /hari.

\section{Waktu paruh}

Laju penurunan antosianin selama proses pemanasan mengikuti waktu paruh ordo 1 yaitu hubungan linier (Kopjar dan Pilizota, 2009). Grafik hubungan antara waktu paruh dengan waktu pemanasan pada suhu $65^{\circ} \mathrm{C}$ ekstrak antosianin terkopigmentasi katekol dapat dilihat pada Gambar 5.

Gambar 5 menunjukkan bahwa konstanta laju penurunan antosianin ekstrak bekatul beras ketan hitam terkopigmentasi katekol pada rasio molar 100:1 lebih kecil yaitu 0,06 mM/jam dibandingkan pada rasio molar 0:1 (0,093 $\mathrm{mM} / \mathrm{jam})$ dan 50:1 (0,08 mM/jam). Hal yang sama ditunjukkan oleh waktu paruh, dimana rasio molar 100:1 memiliki waktu paruh tertinggi yaitu 11,36 jam atau lebih lama dari pada waktu paruh perlakuan rasio molar 0:1 dan 50:1 yang memiliki waktu paruh berturut-turut 7,45 jam dan 8,66 jam.

Konstanta $\mathrm{k}$ dan waktu paruh menunjukkan bahwa rasio molar 100:1 memiliki tingkat degradasi antosianin 
terkecil per jamnya atau lebih dapat memperlambat laju degradasi antosianin dibandingkan dengan rasio molar 0:1 dan 50:1. Menurut Palamides dan Markakis (1978), peningkatan degradasi antosianin selama pengolahan dan penyimpananberbanding lurus dengan peningkatan suhu. Degradasi ini disebabkan kerusakan struktur antosianin seperti yang dilaporkan oleh Giusti dan Wrolstad (2001) bahwa naiknya suhu akan menginduksi rusaknya struktur antosianin melalui mekanisme hidrolisis ikatan glikosidik antosianin dan menghasilkan aglikon-aglikon yang labil serta terbukanya cincin pirilium sehingga terbentuk cincin karbonol dan kalkon yang tidak berwarna.

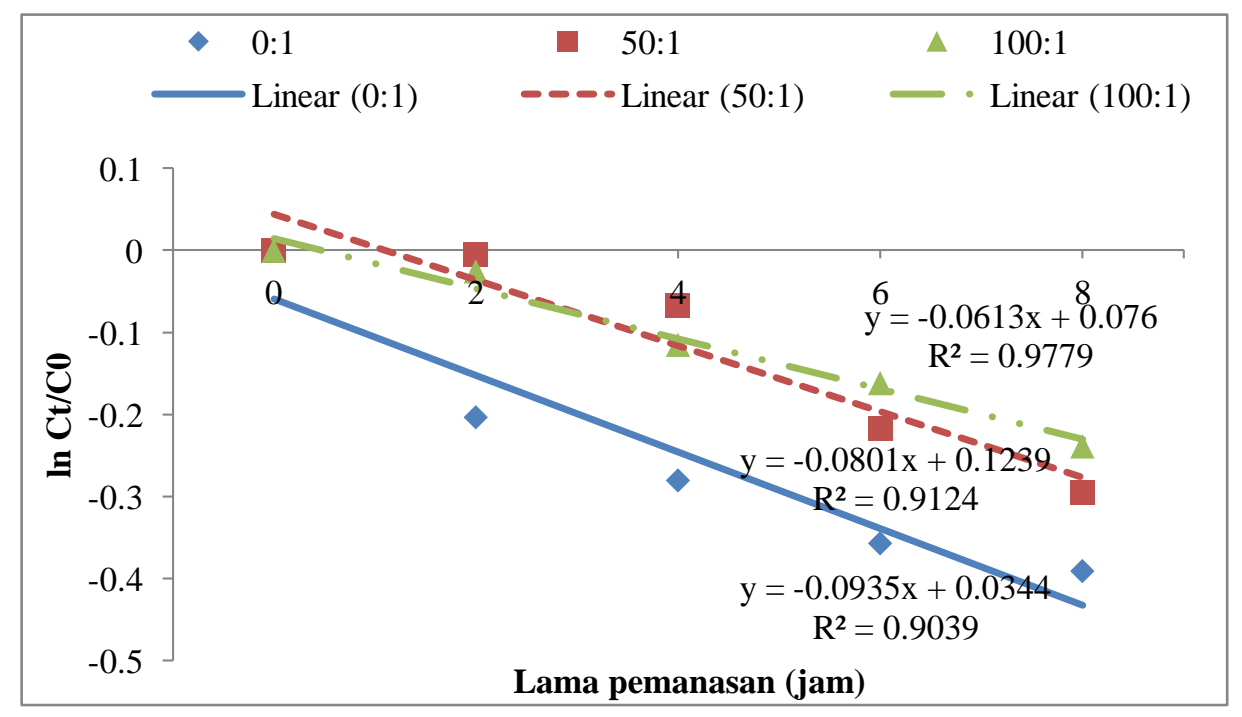

Gambar 5. Grafik hubungan antara $\ln \mathrm{C}_{\mathrm{t}} / \mathrm{C}_{0}$ dengan waktu pemanasan pada suhu $65^{\circ} \mathrm{C}$ ekstrak antosianin terkopigmentasi katekol

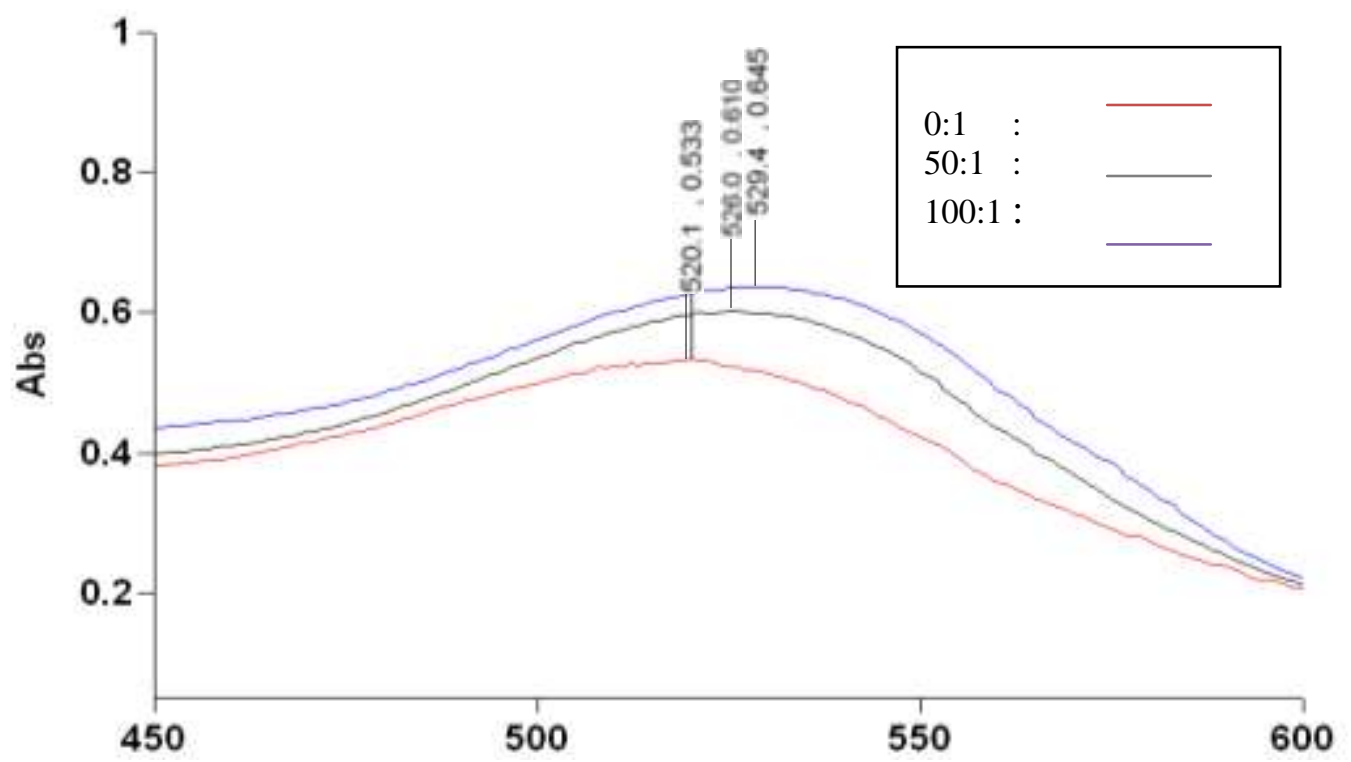

Gambar 6. Pengaruh kopigmentasi tanin terhadap hiperkromik dan batokromik antosianin ekstrak bekatul beras ketan hitam 


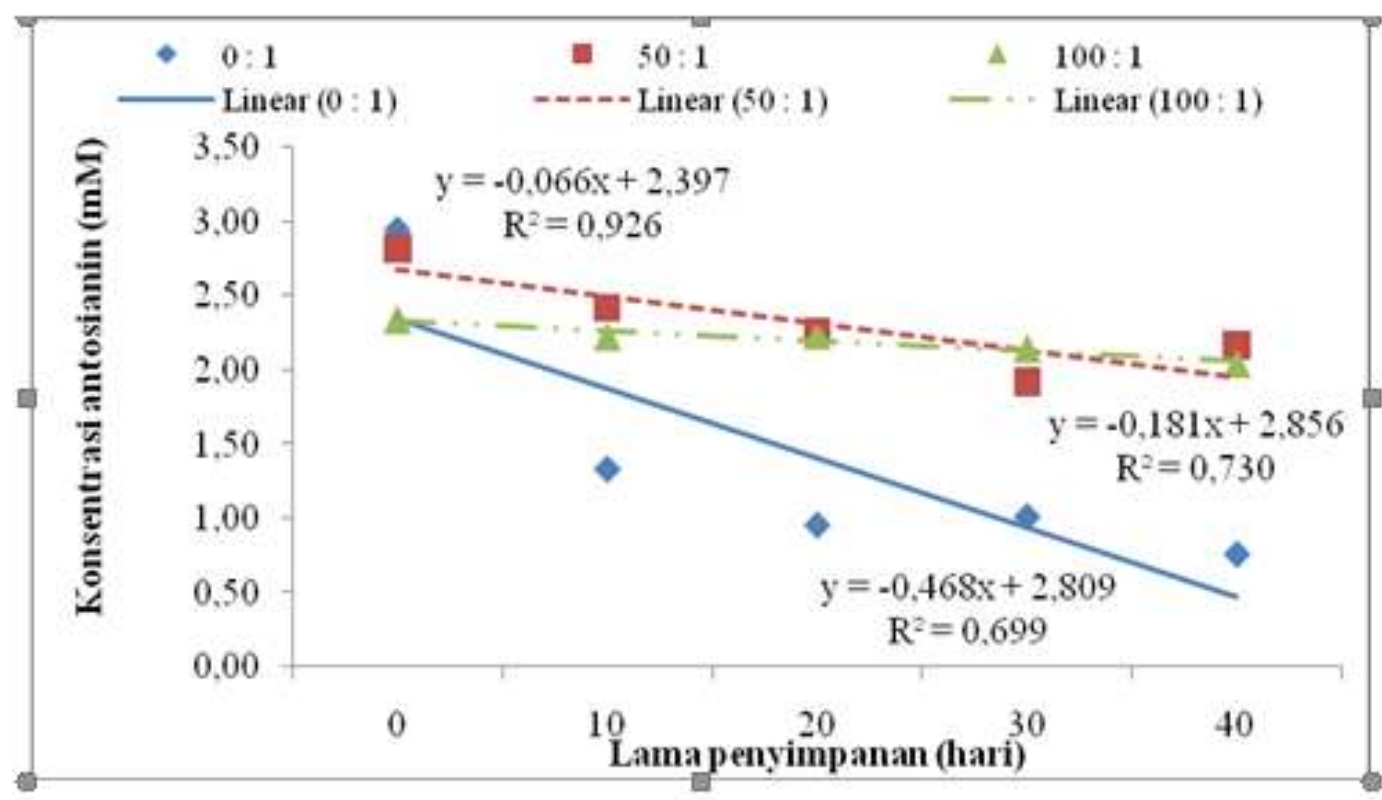

Gambar 7. Pengaruh kopigmentasi tanin terhadap konsentrasi antosianin ekstrak bekatul beras ketan hitam selama waktu penyimpanan

\section{Perubahan konsentrasi antosianin selama penyimpanan}

Hasil analisis ragam menunjukkan bahwa perbandingan rasio molar tanin, lama penyimpanan, dan interaksi keduanya berpengaruh sangat nyata terhadap konsentrasi antosianin pada taraf $1 \%$ dan 5\%. Hasil uji kontras menunjukkan bahwa rasio molar 0:1, 50:1dan 100:1 berpengaruh sangat nyata secara linier (Gambar 7).

Antosianin ekstrak bekatul beras ketan hitam terkopigmentasi tanin pada perbandingan rasio molar 100:1 lebih stabil dibandingkan pada rasio molar 50:1 dan kontrol yang ditujukkan oleh penurunan konsentrasi antosianin terkecil yaitu $\quad 0,07 \mathrm{mM} /$ hari atau 7,86 $\mathrm{mg} / 100 \mathrm{~g} / \mathrm{hari}$. Jumlah penurunan antosianin pada rasio molar 100:1 lebih kecil dibandingkan dengan rasio molar 50:1 dan 0:1 yang mengalami penurunan konsentrasi antosianinberturut-turut sebanyak $0,18 \mathrm{mM} /$ hari dan $0,47 \mathrm{mM} /$ hari.

\section{Perubahan retensi warna}

Hasil perhitungan analisis ragam menunjukkan bahwa perbandingan rasio molar tanin lama penyimpanan, dan interaksi keduanya berpengaruh sangat nyata terhadap retensi warna antosianin pada taraf $1 \%$ dan 5\%. Hasil uji kontras menunjukkan bahwa kopigmen katekol pada rasio molar 0:1 50:1 dan 100:1 berpengaruh sangat nyata secara linier (Gambar 8).

Kopigmen tanin pada rasio molar 100:1 dapat mempertahankan stabilitas antosianin ekstrak bekatul beras ketan hitam terbaik yang ditunjukkan oleh laju penurunan retensi warna antosianin terkecil yaitu 2,39 \%/hari. Pada penambahan rasio molar 0:1 dan 50:1 laju penurunan retensi warna antosianin ekstrak bekatul beras ketan hitam lebih tinggi yaitu $15,92 \%$ /hari dan $6,45 \%$ /hari.

\section{Waktu paruh}

Laju penurunan antosianin selama proses pemanasan mengikuti waktu paruh 
ordo 1 yaitu hubungan linier (Kopjar dan Pilizota, 2009). Grafik hubungan antara waktu paruh dengan waktu pemanasan pada suhu $65^{\circ} \mathrm{C}$ ekstrak antosianin terkopigmentasi tanin dapat dilihat pada Gambar 9.

Gambar 9 menunjukkan bahwa konstanta laju penurunan antosianin ekstrak bekatul beras ketan hitam terkopigmentasi tanin pada rasio molar 100:1 lebih kecil yaitu $0,04 \mathrm{mM} / \mathrm{jam}$ dibandingkan pada rasio molar 0:1 dan $50: 1$ berturut-turut $(0,10 \mathrm{mM} / \mathrm{jam})(0,06$ $\mathrm{mM} / \mathrm{jam})$. Hal yang sama ditunjukkan oleh waktu paruh, dimana rasio molar 100:1 memiliki waktu paruh tertinggi yaitu 19,80 jam atau lebih lama dari pada waktu paruh perlakuan rasio molar 0:1 dan 50:1 yang memiliki waktu paruh berturut-turut 7,45 jam dan 12,16 jam.

Konstanta k dan waktu paruh pada grafik menunjukkan bahwa penggunaan kopigmen tanin pada rasio molar 100:1 memiliki tingkat degradasi antosianin terkecil atau lebih memperlambat laju degradasi antosianin dibandingkan dengan rasio molar 0:1 dan 50:1. Menurut Khaldun, I (2013) suhu ekstraksi dan proses penyimpanan dapat menyebabkan kerusakan dan perubahan antosianin yang terjadi secara cepat, melalui tahapan yaitu terjadinya hidrolisis pada ikatan glikosidik antosianin menghasilkan aglikon-aglikon yang labil; dan terbukanya cincin aglikon sehingga terbentuk gugus karbinol dan kalkon yang tidak berwarna.

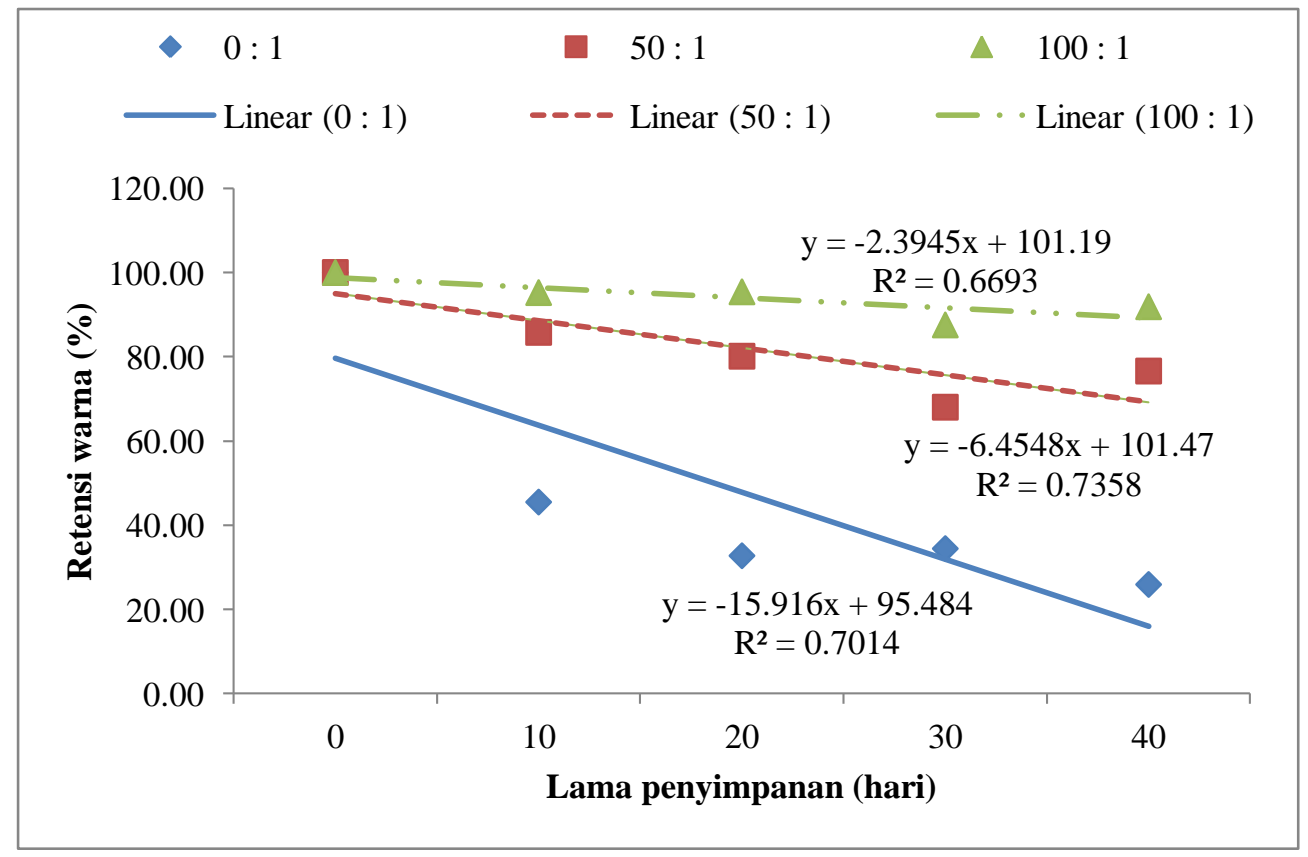

Gambar 8 Pengaruh kopigmentasi tanin terhadap retensi warna antosianin ekstrak bekatul beras ketan hitam selama waktu penyimpanan 


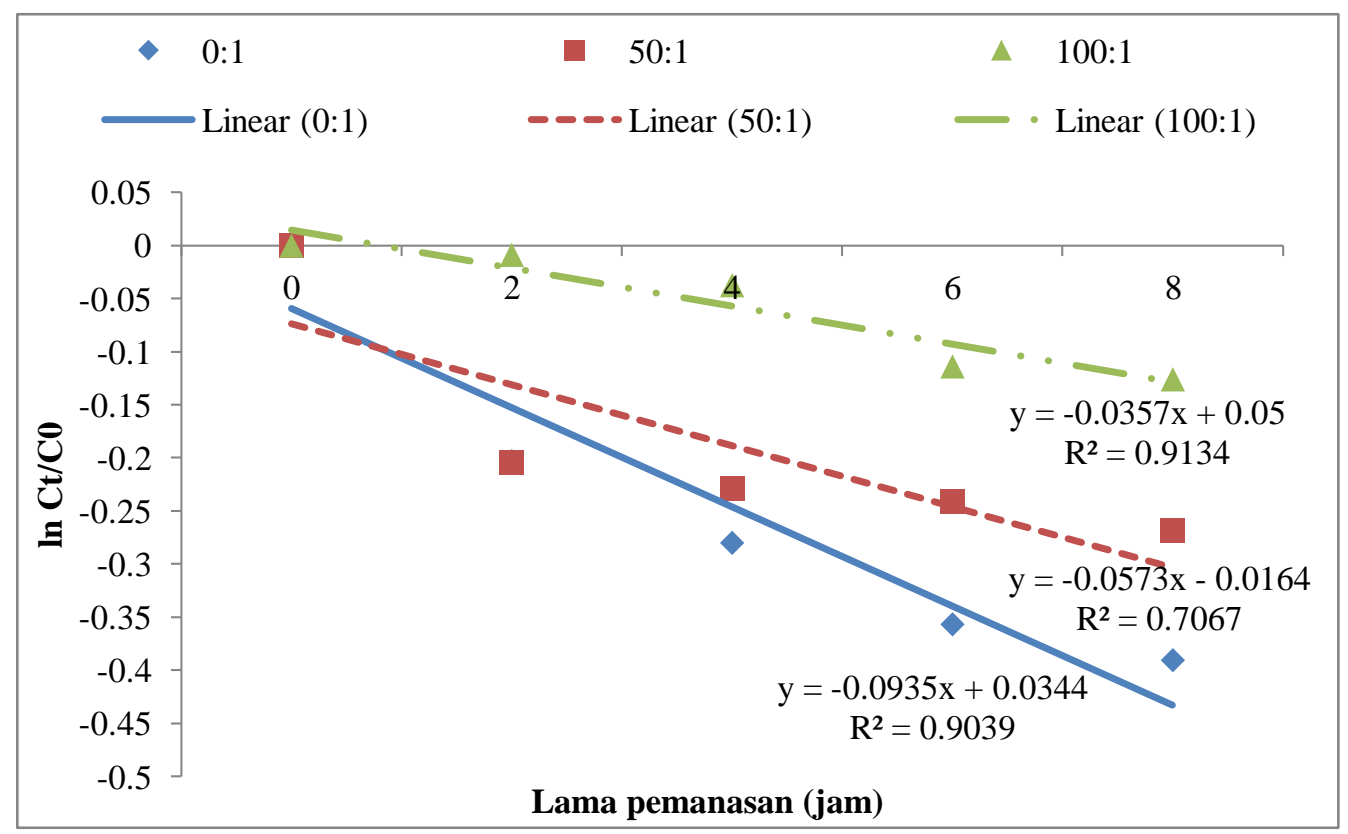

Gambar 9. Grafik hubungan antara $\ln \mathrm{C}_{\mathrm{t}} / \mathrm{C}_{0}$ dengan waktu pemanasan pada suhu $65^{\circ} \mathrm{C}$ ekstrak antosianin terkopigmentasi tanin

\section{KESIMPULAN}

Berdasarkan hasil penelitian yang telah dilakukan, dapat disimpulkan beberapa hal sebagai berikut:

Kopigmentasi ekstrak bekatul beras ketan hitam dengan tanin lebih efektif dibandingkan katekol karena tanin memberikan warna kemerahan (batokromik) dan efek hiperkromik pada rasio molar 100:1 sedangkan katekol walaupun menunjukkan efek penguatan warna (hiperkromik) pada rasio molar kopigmen 100:1, tetapi memberikan pengaruh warna kebiruan (hipsokromik).

Stabilitas antosianin terkopigmentasi tanin lebih efektif dibandingkan katekol yang ditunjukkan oleh laju penurunan konsentrasi antosianin terkopigmentasi katekol 0,36 $\mathrm{mM} / \mathrm{hari}$ atau 39,29 $\mathrm{mg} / 100 \mathrm{~g} / \mathrm{hari}$ sedangkan laju penurunan konsentrasi antosianin terkopigmentasi tanin $0,07 \mathrm{mM} /$ hari atau $7,86 \mathrm{mg} / 100$ $\mathrm{g} /$ hari. Laju penurunan retensi warna antosianin terkopigmentasi katekol $12,78 \%$ /hari sedangkan antosianin terkopigmentasi tanin 2,39\%/hari. Waktu paruh pada suhu $65^{\circ} \mathrm{C}$ antosianin terkopigmentasi katekol 8,66 jam sedangkan antosianin terkopigmentasi tanin 19,80 jam.

\section{DAFTAR PUSTAKA}

Berké, B. and V.A.P. Freitas. 2005. Influence of procyanidin structures on their ability to complex with oenin. Food Chemistry. 90 (3): 453-460.

Boulton, R. 2001. The copigmentation of anthocyanins and its role in the color of red wine: a critical review. Am. J. Enol. Vitic.. 52(2): 67-87.

Castaneda-Ovando A., M.L. PachecoHernandez, M.E. PaezHemandez, J.A. Rodrigue and C.A. Galan-Vidal. 2009. Chemical studies of anthocyanins: a review. Food Chemistry. 133: 859-971. 
Darias-Martin, J., M.C. Lopez, J.F.E. Granado and C.D. Romero. 2007. The Magnitude of Copigmentation In The Colour of Aged Red Wines Made in the Canary Islands. European Food Research and Technology, 224(5):643-648.

Francis, F.J. and I.A. Bassa. 1987. Stability of Anthocyanin from Sweet Potatoes in a Model Beverages. Journal of Food Science. 52 (6) : 1753-1754.

Gao, K. and G. Mazza. 1996. Extraction on Anthocyanin Pigments from Purple Sun Flower Hulls. Journal of Food Science. 61(3): 600-603.

Gauce C., E.S. Malagoli, and M.T.B. Luiz. 2010. Effect of ph on the copigmentation of anthocyanins from carbernet sauvigon grape extracts with organic acid. Science Agricuture (Piracicaba, Braz.), 67 (1):41-46.

Giusti, M. M., and Wrolstad, R. E. 2001. Anthocyanins. Characterization and measurement with uv-visible spectroscopy. InR.E. Wrolstad (Ed.). Current Protocols in Food Analytical Chemistry. New York :Wiley.

Jackman, R.L. and J.L Smith. 1996. Anthocyanin and betalains. Natural Food Colourants. Second Edition. Blackie Academic and Profersionals. London.

Kalisz, S., J. Oszmianski, J. Hladyszowski and M. Mitek. 2013. Stabilization of anthocyanin and skullcap flavone complexes investigations with computer simulation and experimental methods. Polandia. Food Chemistry, 138(1):491-500.

Khaldun, I.. 2013. Kestabilan zat warna alami dari umbi ketela ungu (Ipomoea batatas). J Chimica Didactica Acta. 1 (1):34-40.

Kopjar, M. and V. Pilizota. 2009. Copigmentation effect of phenolic compounds on red currant juice anthocyanins during storage. J. Food Sci Technol. 1(2):16-20.

Mahkamah, S. 2004. Perbandingan Stabilitas Panas Ekstrak Antosianin Bekatul Beras Ketan Hitam (Oryza sativa glutinosa) dan Tanaman Hati Ungu (Tradescantia pallida). Skripsi. Universitas Lampung. Lampung.

Markovic, J.M.D., N.A. Petranovic, and J.M. Baranac. 2000. A Spectrophotometric Study of the Copigmentation of Malvin with Caffeicand Ferulic Acids. J Agric Food Chem, 48:55305536.

Mastuti, E., G. Fristianingrum, dan Y. Andika. 2013. Ekstraksi dan Uji Kestabilan Warna Pigmen Antosianin dari Bunga Telang (Clitoria ternatea L.) sebagai Bahan Pewarna Makanan. Simposium Nasional RAPI XII. ISSN 1412-9612. Universitas Sebelas Maret.

Mateus N., and V. Freitas.2008. Anthocyanins as Food Colorants. In: Winefield C., Davies K., Gould K. (eds) Anthocyanins. Springer, New York, NY. Pp $284-304$.

Mazza G. and R. Brouillard. 1990. The Mechanism of Copigmentation of Anthocyanins in Aqueous Solutions. Phytochemistry, 29:1097-1102.

Pebrianti, C., R.B. Ainurrasyi dan S.L. Purnamaningsih. 2015. Uji kadar antosianin dan hasil enam varietas tanaman bayam merah. Jurnal Produksi Tanaman 3(1): 27-33.

Palamides, N. and P. Markakis., 1978. Stability of Grape Anthocyanin in Carbonated Beverages. Semana Vitivicola 33: 26332639.

Rein, M.J. dan M. Heinonen. 2004. Stability and Enhancement of 
Berry Juice Color. J. Agric.

Food Chemistry. 52 (25):3106-

3114

Rein, M.J. 2005. Copigmentation

Reactions and Color Stability of Berry Anthocyanins. Doctoral Manuscript. University of Helsinki Department of Applied Chemistry and Microbiology Food Chemistry Division. Helsinki. 87 pp.

Setyadi, R. 2014. Penentuan Kandungan Total Antosianin pada Berbagai Bunga dengan Metoda Spektrofotometri $\mathrm{pH}$ Differential. Thesis. Universitas Andalas. Padang.

Scheffeldt, P. and G. Hrazdina, 1978. Copigmentation of anthocyanins under physiological conditions. Journal of Food Science. 43 (2):517-520.

Shao Y., F. Xu, X. Sun, J. Bao, and T. Beta. 2014. Identification and quantification of phenolic acid and anthocyanins as antioxidants in bran, embryo, and endosperm of whine, red, and black rice kernels (Oryza sativa L). Journal Cereal Science. 59:211-218.

Shi, Z. and F.J. Francis, 1992. Anthocyanins of tradescantiapallida: potential food colorants. Journal of Food Science. 57(3): 761-765.

Steel R.G.D. and J.H. Torrie. 1991. Prinsip dan Prosedur Statistika. PT. Gramedia. Jakarta.

Talcott ST, C.H. Brenes, D.M. Pires and D.D. Pozo-Insfran. 2003. Phytochemical stability and color retention of copigmented and processed muscadine grape juice. J Agric Food Chem. 51(4): 957963

Wilska-Jeszka $\mathrm{J}$ and A. Korzuchowska. 1996. Anthocyanins and Chlorogenic Acid Copigmentation. Influence on the Color of Strawberry and Chokeberry Juices. Lebensm Unters Forsch. 203(1):38-42. 